\title{
Adult demography, dispersal and behaviour of Brenthis ino (Lepidoptera: Nymphalidae): how to be a successful wetland butterfly
}

\author{
KAMIL ZIMMERMANN ${ }^{1}$, ZDENĚK FRIC ${ }^{1,2}$, LADISLAVA FILIPOVÁ ${ }^{3}$ and MARTIN KONVIČKA ${ }^{1,2 *}$ \\ ${ }^{1}$ Department of Zoology, School of Biological Sciences, University of Southern Bohemia, Brani šovská 31, 37005 České \\ Budějovice, Czech Republic \\ ${ }^{2}$ Department of Ecology and Conservation, Institute of Entomology, Czech Academy of Sciences, Brani šovská 31, 37005 České \\ Budějovice, Czech Republic \\ ${ }^{3}$ Department of Botany, Faculty of Sciences, Palacký University Olomouc, Šlechtitelů 13, Olomouc, Czech Republic.
}

\begin{abstract}
Key words. Argynnini, Nymphalidae, Brenthis ino, behaviour, butterfly ecology, dispersal, habitat quality, grasslands, host plant
\end{abstract} range, metapopulation

\begin{abstract}
Continent-wide loss of traditionally managed humid meadows is raising concern for associated butterfly specialists across Europe. However, not all species associated with this biotope are threatened, and the Lesser Marbled Fritillary (Brenthis ino) has even spread locally. We employed mark-recapture and transect walks to study its population structure and patterns of landscape occupancy in a hilly region of western Bohemia, Central Europe, to determine which life history or demography traits might be responsible for its success. A population studied by mark-recapture harboured more than 1000 individuals and was interconnected with other populations. This was further supported by a fit of the inverse power function to dispersal data. Observations of adult behaviour revealed a broad host plant range: at least three species of plants were used by the single population. On a landscape scale, the butterfly exhibited an aggregated distribution matching its host plants. It was associated with the distribution of characteristic plants and butterflies of semi-natural humid meadows, but its frequency exceeded those of other humid grasslands specialists. The relatively broad host range coupled with varying biotope requirements of individual host plant species results in a wide biotope range for the butterfly, explaining its persistence in fragmented Central European landscapes.
\end{abstract}

\section{INTRODUCTION}

Throughout Europe, agricultural intensification, irrigation and yield improvement schemes, and abandonment of less-productive land, have caused serious declines of butterflies associated with traditionally managed humid meadows (Van Swaay \& Warren, 1999; Maes \& Van Dyck, 2001; Beneš et al., 2002). Such losses urge the collection of detailed ecological information on individual species that can be directly applied to practical conservation measures (e.g., Neve et al., 1996; Fisher et al., 1999; Anthes et al., 2003; Baguette \& Schtickzelle, 2003; Konvička et al., 2003; Schtickzelle \& Baguette, 2004). The focus on declining species, however, results in neglect of butterflies that have evaded decline and have even spread. Arguably, this restricts our understanding of species persistence in fragmented landscapes. It is little known, for instance, whether species avoid decline owing to less specialised requirements and hence access to a wider range of biotopes, or whether they posses some demographic traits, such as better dispersal ability, which allows them to track habitable areas more efficiently. In the case of widespread generalists, a combination of the above conditions may be responsible, although a denser distribution of resources seems to correlate more commonly with successes (Sutcliffe et al., 1997; Schneider et al., 2003). The question is, what factors affect the apparent success of non-declining specialists.
The Lesser Marbled Fritillary, Brenthis ino (Rottemburg, 1775), represents an apparently successful species of humid meadows. Its distribution is stable in Europe. Although it has disappeared from one country (the Netherlands) and has declined in a few others, it is increasing elsewhere, e.g., in the Czech Republic, Hungary, Slovakia and Slovenia (Van Swaay \& Warren, 1999). In the Czech Republic, the increase is accompanied by colonisation of previously unoccupied lowlands (Švestka, 1992; Beneš et al., 2002). The expansion has been attributed to expansion of its larval host plant, Filipendula ulmaria, facilitated by abandonment of active management of riparian grasslands (Švestka, 1992). However, the basic life history of the butterfly remains so little known that the hypothesis remains unsupported. In any case, the increase stands in striking contrast to severe declines of other species of humid meadows, such as Melitaea diamina (Lang, 1789), Euphydryas aurinia (Rottemburg, 1775) and Lycaena helle (Denis \& Schiffermüller, 1775) (cf. Beneš et al., 2002). B. ino thus provides a suitable model for studying mechanisms of persistence of specialised species in fragmented landscapes.

Here, we present results of a study on adult demography of $B$. ino in a submontane landscape in western Bohemia, Czech Republic. It is based on a survey of the distribution of the butterfly in a section of landscape, mark-recapture study of adult demography, and records of adult behaviour and resource use. We ask, which life

\footnotetext{
* Corresponding author; e-mail: konva@entu.cas.cz
} 
history and demography traits might be responsible for the apparent success of $B$. ino in fragmented landscapes of Central Europe. By reporting our behavioural observations, we also fill a gap in the basic knowledge of life history of the species.

\section{METHODS}

\section{Study species}

B. ino is a Palaearctic species distributed from W. Europe to the Ussuri region, N. China and Japan. Apart from the British Islands and extreme South, it inhabits entirety of Europe (Tolman \& Lewington, 1997). Principal biotopes in C. and W. Europe include humid to wet grasslands, riverine marshes, bogs, clearings in wet forests, mountain valleys and subalpine tallherb formations. In the Czech Republic, post-1980 distribution covers 270 grid squares, or $35 \%$ of the country (Beneš et al., 2002).

Individual development is univoltine, adults are on the wing from late June until mid-August. Males use patrolling to search for females, females lay eggs singly and larvae feed solitarily. Regarding host plant use, there is contradictory information in the literature. The most frequently reported plant species are Filipendula ulmaria, Sanguisorba officinalis and Rubus spp., but some authors mention Aruncus vulgaris, Potentilla palustris, Sanguisorba minor, and a few other plant species (e.g., Hrubý, 1964; Henriksen \& Kreutzer, 1982; SBN, 1987; Ebert \& Rennwald, 1991; Tolman \& Lewington, 1997; Settele et al., 1999; Agnes, 2000; Sawchik et al., 2003). Hence, it seems that B. ino is associated with various Rosaceae, perhaps with a trophic range varying with geographic locality.

Plant nomenclature follows Kubát (2002) and butterfly nomenclature follows Karsholt \& Razowski (1996).

\section{Study area and design}

The study was carried in the vicinity of Karlovy Vary, western Czech Republic $\left(50^{\circ} 9^{\prime} \mathrm{N}, 13^{\circ} 2^{\prime} \mathrm{E}\right.$, altitude $\left.650 \mathrm{~m}\right)$, on a hilly piedmont of the volcanic Doupovske Mts. The landscape is a fine-grained mosaic of both extensively used and improved meadows, pastures, ponds, small woodlots and shrubby foreststeppes on basaltic outcrops. Remnants of wet, extensively used meadows constitute a Czech stronghold for several declining butterflies, most notably Euphydryas aurinia (cf. Konvička et al., 2003; Hula et al., 2004).

We conducted two parallel surveys in summer 2004. One was a transect-based census of butterflies in a wider landscape, the other was a mark-release-recapture (MRR) survey of selected colonies. The transects intersected the area of the MRR survey (Fig. 1), facilitating a comparison of the observational and MRR results.

\section{Mark-recapture}

The MRR study was carried out in a system of semi-natural humid meadows, separated by ponds, shrubby hedges and woodlots. They are managed by mowing once a year, but less accessible or waterlogged parts, varying in extend from year to year, are temporarily left unmown. The meadows form an approximate crescent adjoining a large species-poor improved meadow; the total area was 28 ha. The centroids of thirty individual meadow fragments (mean area $=0.9$ ha, $S D=0.64$ ha), distinguishable by prominent landmarks, were used for analysing mobility.

The study was conducted from 21 June, when we observed the first individual, until 5 August. Each day, weather permitting, one to three persons traversed each of the meadow fragments; the time spent within each fragment was proportional to

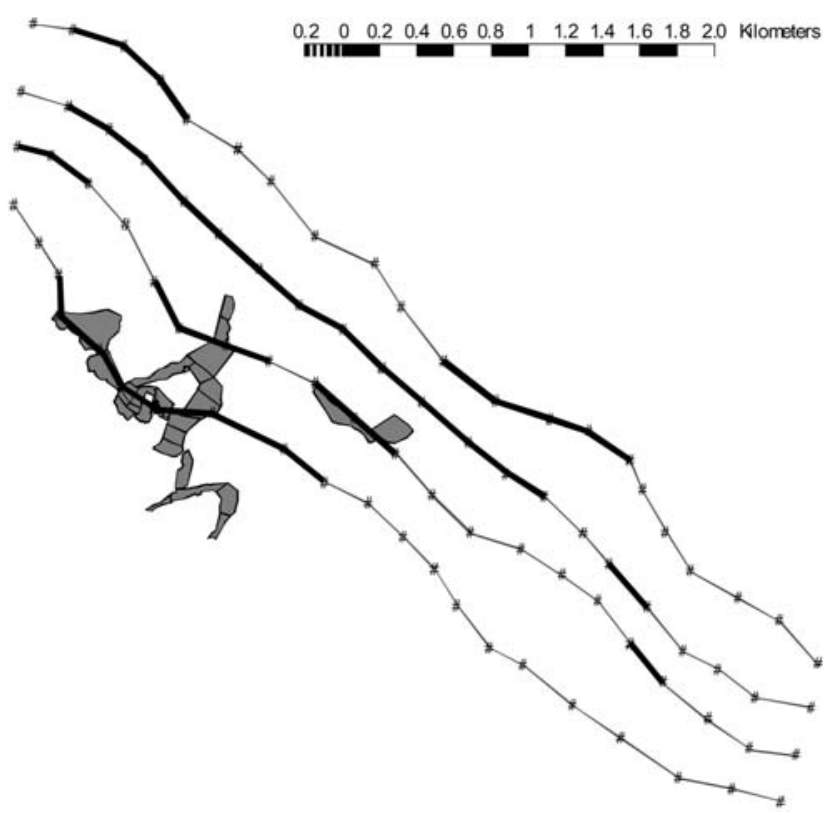

Fig. 1. Map of the study area showing the humid meadows where the mark-recapture study was carried out, and the four transect routes dissecting the meadows. Thick lines show segments occupied by Brenthis ino.

fragment size. As many butterflies as possible were captured and marked with unique numbers; their sex, wing wear (1-4 scale, 1 being fresh and 4 being heavily worn) and position of capture were noted before releasing them at capture points. We also recorded behaviour prior to capture, distinguishing "flight", "patrolling" (searching flight distinguished in males only), basking, resting, egg-laying, mating and nectaring. For nectaring, we recorded the plant used.

To estimate daily population sizes $\mathrm{N}_{\mathrm{i}}$, we used the analytical Jolly-Seber method computed as model A in the program JOLLY (Pollock et al., 1990). The method is appropriate for open populations subject to births, deaths, immigration and emigration. The estimates are based on numbers of marked animals, estimates of daily residence $\left(\varphi_{i}-\right.$ this combines survival and the probability of staying in a population) and daily numbers of animals at risk of being captured. It does not return a "total" population size, which would be meaningless for open population systems.

To estimate average residence, we used the variance weighted averaging (Tabashnik, 1980), which weights the JOLLYestimated $\mathrm{j}_{\mathrm{i}} \mathrm{s}$ by the reciprocals of their standard errors $V\left(\varphi_{\mathrm{i}}\right)$

$$
\varphi_{V}^{\prime}=\frac{\sum{ }_{i=1}^{K-2}\left(\varphi_{i}^{\prime}\right)^{1 / d i}\left[V\left(\varphi_{i}^{\prime}\right)^{-1 / 2}\right]}{\sum{ }_{i=1}^{K-2} V\left(\varphi_{i}^{\prime}\right)^{-1 / 2}}
$$

Average residence times (or "longevities") were obtained as $-\left(\ln \varphi_{V}\right)^{-1}$. All the estimates were performed separately for sexes.

We used the inverse power function (Hill et al., 1996; Kuras et al., 2003) to asses the probabilities of movements to distances beyond those covered by the MRR study. The function has fatter tail than an alternative, the negative exponential function, and hence is more appropriate for predicting rare long-distance movements (Baguette, 2003; Vandewoestijne \& Baguette, 2004). For all butterflies captured more than once, the probability density $I$ of movements to distances $D$ equals:

$$
I_{I P F}=C \cdot D^{-n}
$$


TABLE 1. Summary of mark-recapture data used for analysing demography of Brenthis ino in western Bohemia, Czech Republic.

\begin{tabular}{lccccc}
\hline & individuals captured & individuals recaptured & proportion recaptured & recapture events & maximum residence \\
\hline Males & 1006 & 538 & $53.5 \%$ & 1168 & 30 days \\
Females & 656 & 198 & $30.2 \%$ & 278 & 18 days \\
\hline
\end{tabular}

The parameters $C$ and $n$ are estimated by plotting the logarithm of cumulative fractions of individuals moving specific or greater distances $(\ln l)$ against linearised expressions of the distances, i.e., $\ln I=\ln C-n(\ln \mathrm{D})$. We compared slopes and intercepts of the resulting linear regressions using t-tests (Zar, 1999).

\section{Transect survey}

We delimited four parallel transect routes, each consisting of twenty segments $300 \mathrm{~m}$ long and situated $300 \mathrm{~m}$ apart, thus forming a rectangular grid of $20 \times 4$ segments (Fig. 1). Prevailing biotopes along the routes were meadows and pastures (both unimproved and improved), plus small woodlots, scrub, and arable fields. We walked the routes approximately once every ten days between late May and early August, carrying out eight walks in all. The walks were limited to suitable weather, between 9:30 and 16:00 (C. European summer time), and it took two person-days to walk the entire grid. We counted all butterflies and burnet moths (Zygaenidae) observed. We also recorded plant diversity along the lines by identifying to species all higher plants growing in an approximate $5 \mathrm{~m}$ strip along the route.

We used the butterfly counts to calculate the frequency and abundance of $B$. ino relative to other butterflies. The pattern of aggregation along the transect was assessed by the Morisita index of dispersion (Krebs, 1989). Distributions of the butterfly and its host plants were compared using Mantel's test for two distance matrices (Sorensen's similarity), one based on presence-absence of $B$. ino and one based on presence-absence data of its host plants.

Patterns of association with other butterflies, and with plants, were analysed using redundancy analysis, a linear ordination method that arranges samples according to their species composition, constraining the ordination according to independent "environmental variables". For butterflies, we used presence of individual species, less $B$. ino, as "species data", and the presence/absence of $B$. ino as a categorical predictor. For plants, we again used species presence data as dependent variables and $B$. ino as a predictor. The computations were done in CANOCO for Windows 4.5 (Ter Braak \& Smilauer, 2002), using the Monte-Carlo permutation test (999 runs) for assessing the significance of the ordinations, and considering the spatial structure of the data in permutation designs.

\section{RESULTS}

\section{Demography}

We marked 1662 butterflies and obtained 1446 recaptures during the MRR study (Table 1). Capture sex ratio was male biased $\left(\chi^{2}=32.3,1\right.$ d.f., $\left.p<0.001\right)$, and males were recaptured more often than females $\left(\chi^{2}=35.5,1\right.$ d.f., $\mathrm{p}<0.001)$.

The seasonal recruitment was markedly protandrous. The first male appeared 14 days earlier than the first female (21 June vs. 7 July) and the peak of male flight preceded that of females by about two weeks (Fig. 2). Male recruitment was characterised by a steep increase. The beginning of female flight was less abrupt, and we missed an expected tail of the female flight period in
August. This was further evident from the pattern of seasonal increase of wing wear. When plotted against marking days, the increase was steeper in males $(\beta=$ $0.62, \mathrm{~F}=1287.8$, d.f. $=1,2052, \mathrm{p}<0.001)$ than in females $(\beta=0.32, \mathrm{~F}=80.3, \mathrm{p}<0.001$; comparison of the regression coefficients: $\mathrm{t}=6.3$, d.f. $=274, \mathrm{p}<0.001)$. In addition, daily residence rates tended to decrease with season in males $(\beta=-0.01, F=3.89$, d.f. $=1,36, p=$ $0.06)$, but not in females $(\mathrm{F}=1.19$, d.f. $=1,25, \mathrm{p}=0.29)$. The estimated mean residence rates were 0.87 (males) and 0.80 (females), corresponding to mean residence times of 6.9 and 4.5 days, respectively.

Estimates of adult numbers documented a large population size, with mean values from five peak days being 710 (51 SD) males and 1150 (249 SD) females, corresponding to peak densities of 25 males and 41 females per hectare.

\section{Mobility}

Females moved among individual meadows more frequently than males $\left(\chi^{2}=15.1\right.$, d.f. $\left.=1, \mathrm{p}<0.001\right)$ and covered greater distances between consecutive captures (Mann-Whitney U, Z $=-2.74, \mathrm{p}<0.01$ ) (Table 2).

Fitting mobility using the inverse power function resulted, for males, in the equation, $\ln I=-3.72( \pm 0.100)$ $-1.58( \pm 0.100) \times \ln D$. The fit was highly significant $(\mathrm{F}=$ 126.9 , d.f. $=1,17, \mathrm{p}<0.001)$, with $\mathrm{R}^{2}=0.85$. For females, the equation was $\ln I=-3.60( \pm 0.135)-1.51$ $( \pm 0.110) \times \ln D$. It was again significant $(\mathrm{F}=126.9$, d.f. $=$ $1,17, \mathrm{p}<0.001)$, with $\mathrm{R}^{2}=0.88$.

The two regressions did not differ $(\mathrm{t}=0.47$, d.f. $=45, \mathrm{p}$ $>0.1$ ), suggesting essentially identical dispersal kernels with the exponential parameter $n$ (determining the width of dispersal tail) close to 1.5 . The estimated probabilities

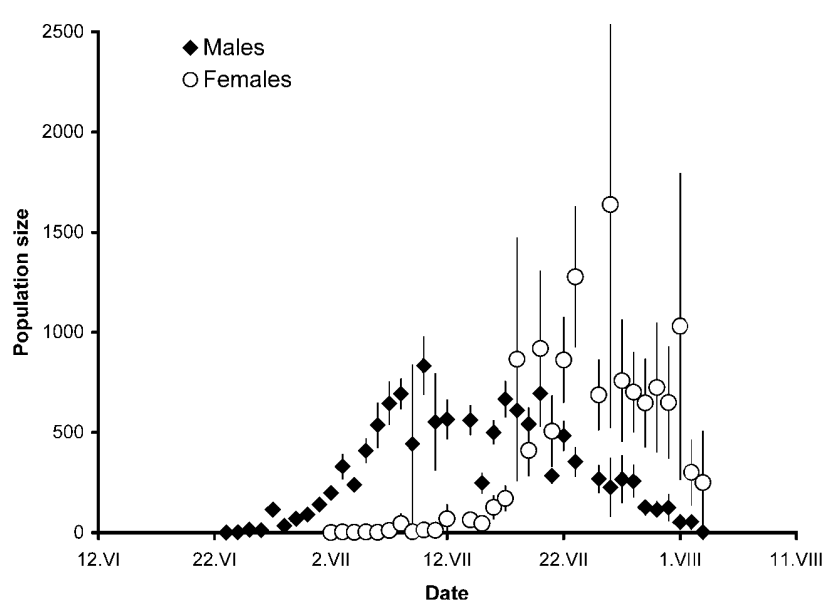

Fig. 2. JOLLY estimates of daily population sizes of Brenthis ino, based on a mark-recapture survey in 2004 in an area of wet meadows in western Bohemia. The error lines are standard errors of the estimates. 
TABLE 2. Summary of mark-recapture data used for analysing mobility of Brenthis ino in western Bohemia, Czech Republic.

\begin{tabular}{lcccc}
\hline Mobility & patch-to-patch movements & mean distance moved & maximum single move* & maximum total distance* \\
\hline Males & 369 & $160 \mathrm{~m}$ (SD 193) & $1310 \mathrm{~m}$ & $2240 \mathrm{~m}$ \\
Females & 141 & $180 \mathrm{~m}$ (SD 180) & $1310 \mathrm{~m}$ & $2120 \mathrm{~m}$ \\
\hline
\end{tabular}

*values per individual butterfly

of long-distance flights were 0.02 for $1 \mathrm{~km}, 0.002$ for 3 $\mathrm{km}$, and 0.0006 (males) or 0.0009 (females) for $5 \mathrm{~km}$. Given the dense distribution of the butterfly in the landscape (see below), it is likely that local colonies were all interconnected by individual dispersal.

\section{Behaviour and host plant choice}

Prevailing behaviour of males observed during the MRR was patrolling (Fig. 3). They patrolled all day in search for females, interrupting this activity only to bask or feed on nectar, whereas females flew less frequently and spent more time feeding. This resulted in a significant difference between sexes $\left(\chi^{2}=283.5\right.$, d.f. $=5, \mathrm{p}<0.001$; male patrolling was merged with flight for this test).

Mating $(n=5)$ occurred low down $(<0.7 \mathrm{~m})$ on herbaceous vegetation; one mating observed from beginning to end lasted $140 \mathrm{~min}$.

Egg-laying was preceded by a short searching flight. Once a female landed on a host plant, she immediately descended towards the ground, located a suitable leaf near the ground, flexed her abdomen upwards and deposited one egg on leaf underside, close to the leaf base. She

\section{Males}

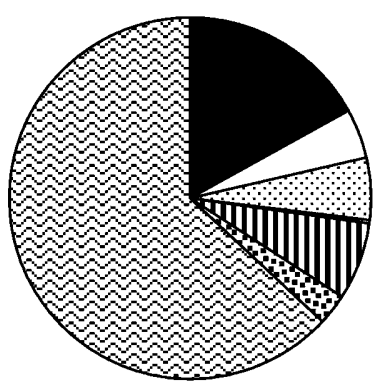

Basking

口Flight

응 Chasing

乙Oviposition

I Nectaring

国 Resting

QPatrolling

\section{Females}

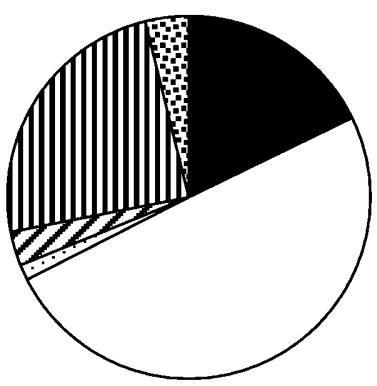

Fig. 3. Types of behaviour prior to capture observed during the mark-recapture study of Brenthis ino. then worked her way upwards, basked for a few seconds and flew a few meters away, where she continued basking for further 8-15 min. Many of the basking or egg-laying activities observed during MRR (Fig. 3) were probably associated with oviposition.

We observed 23 eggs being laid. The host plants used were Sanguisorba officinalis (19), Potentilla erecta (3) and Comarum palustre (1). The females did not seem to discriminate with respect to height of vegetation. After 16 July, about two thirds of the meadows were mown, and we repeatedly observed females visiting the mown parts and ovipositing on regenerating Sanguisorba officinalis. We failed to observe oviposition on Filipendula ulmaria, although the plant was common in the study area and formed dense growths along meadow edges. However, we often encountered females alighting on clumps of the plant. Because $F$. ulmaria is a tall, bulky herb, we can not exclude the possibility that it is used as host plant, but we failed to observe it.

Fig. 4 presents nectaring records. Although the butterfly uses a wide array of plants, over half of all observations were on just three species in both sexes. The differences between sexes in relative importance of nectar sources reflected a phenological shift in plant flowering times.

\section{Distribution in wider landscape}

We obtained 8717 records of 54 butterfly species from the transect survey. Means/medians per segment were 109 ( $\pm 62.3 \mathrm{SD}) / 99$ individuals, and $14( \pm 4.0 \mathrm{SD}) / 14$ species. The abundances per species were closely correlated with frequencies (Spearman's $s=0.96, \mathrm{t}=24.0$, d.f. $=52, \mathrm{p}<$ $0.001)$, and both measures were distinctly left-skewed (mean/median frequencies: $21 \quad( \pm 19.3 \quad \mathrm{SD}) / 11$; mean/median abundance: 161 ( $\pm 218.3 \mathrm{SD}) / 20)$.

Brenthis ino was observed in 36 segments $(45 \%$ of the total), numbering 390 individuals (mean per segment: 5.0 $\pm 6.7 \mathrm{SD}$ ) and ranking as the thirteenth most frequent and ninth most abundant species. Most of the butterflies exceeding it in frequency and abundance are widespread in C. Europe (e.g. Aglais urticae, Aphantopus hyperanthus, Maniola jurtina, Coenonympha pamphilus, Thymelicus lineola). The only biotope specialists exceeding $B$. ino in both abundance and frequency were Polyommatus amandus and Erebia medusa. Of course, the abundance ranking could have changed by extending the walks towards early May/late August, but the changes would unlikely affect the overall pattern radically. In particular, the period covered by the observations included flight periods of all wet meadows specialists.

Of the 390 observations of $B$. ino, 122 (32\%) originated from the MRR area. Considering that there were about 1900 butterflies during the peak flight time we estimated 
Male nectar sources $(\mathrm{N}=123)$

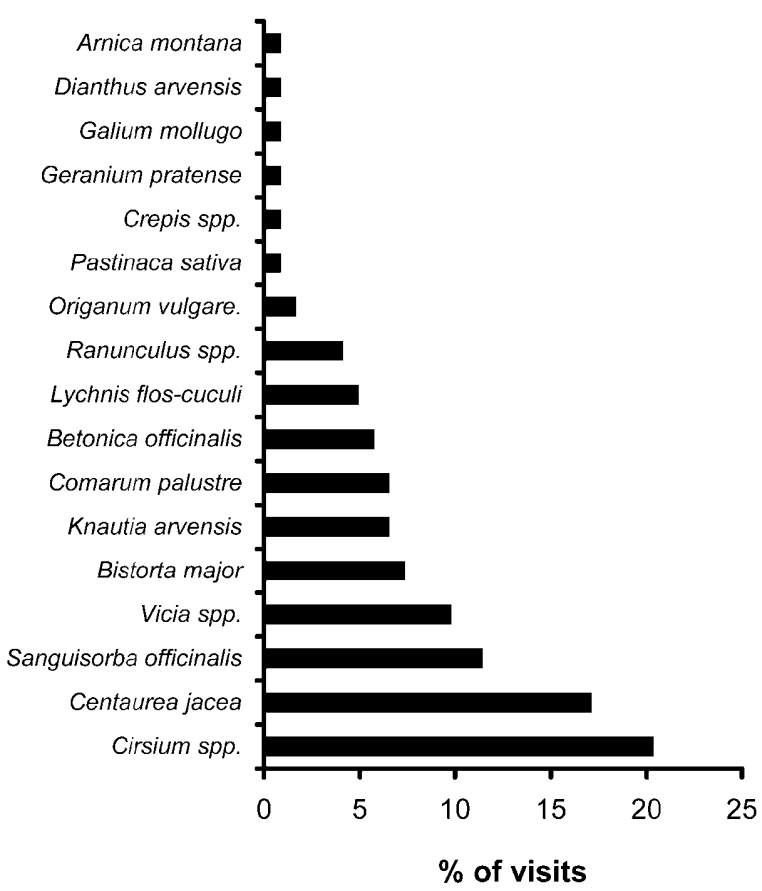

Female nectar sources $(\mathrm{N}=\mathbf{2 1 7})$

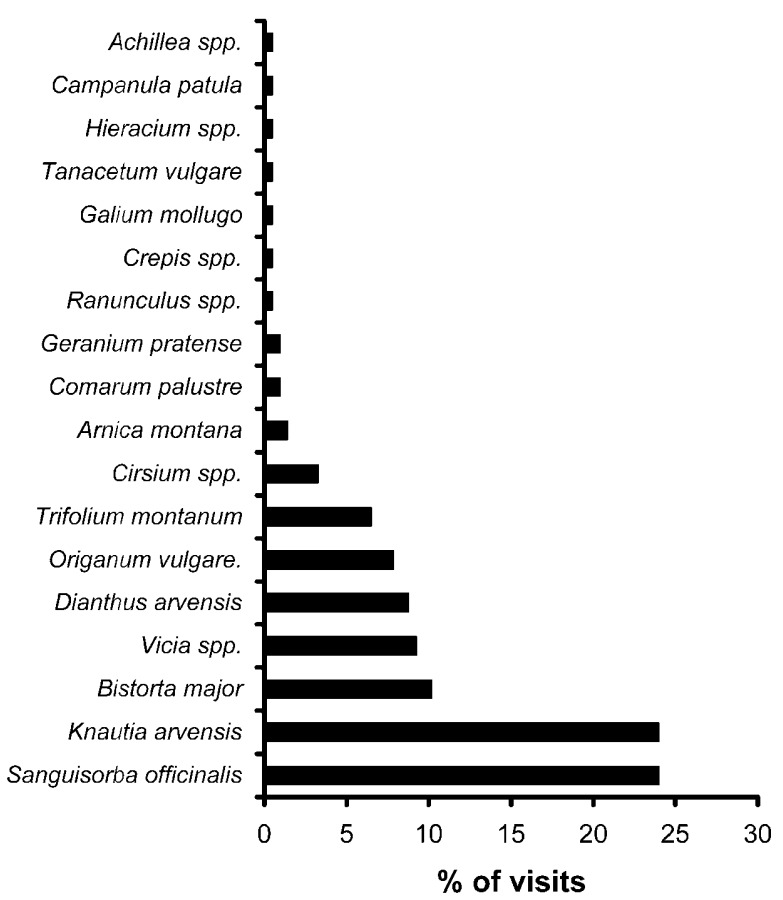

Fig. 4. Use of nectar plants by males and females of Brenthis ino, recorded during mark-recapture survey.
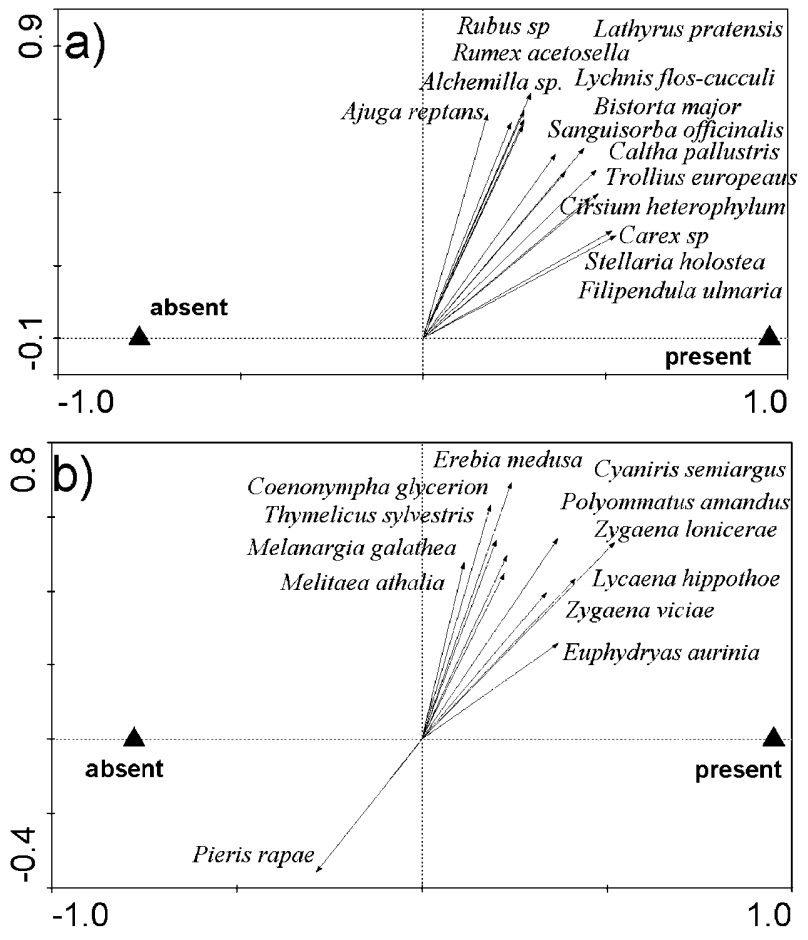

Fig. 5. Ordination diagrams (redundancy analysis) showing association of Brenthis ino with plants and butterflies recorded along transect routes. The ordinations are based on presenceabsence data, with presence/absence of $B$. ino as an independent categorical predictor. Only species with the highest fit in the models are shown for clarity. (a) Plants: eigenvalues of the first and second axes: 0.078 and 0.037 ; Monte-Carlo permutation test of significance of the first axis: $\mathrm{F}=5.68, \mathrm{p}<0.01$; (b) Butterflies: Eigenvalues: 0.056 and 0.143 ; test: $F=4.59, \mathrm{p}<0.01$. the occurrence of some 6000 butterflies in the landscape covered by the transect.

The distribution of $B$. ino along the transect was highly aggregated (Morisita index of dispersion $=0.06$ ). Despite this, the longest distance separating two occupied segments was $1080 \mathrm{~m}$, which was within a range easily crossed by dispersers. Its host plants were present in either 42 (including Filipendula ulmaria) or 36 (excluding it) segments, and the distributions of the butterfly matched that of the plants (Mantel test, $p=0.94$ ). The longest distances separating segments with host plants were as little as $300 \mathrm{~m}$, suggesting that dispersing females should easily be able to locate host plant biotopes.

Both ordination of plants (Fig. 5a) and butterflies (Fig. $5 b)$ corroborated a close association of $B$. ino with characteristic species of humid meadows. The positions of the ten most closely associated butterflies (according to species scores on the first ordination axis) on a rankfrequency plot (Fig. 6) shows that $B$. ino was the third most frequent associated species, surpassing, both in frequency and in abundance, all other characteristic wet meadow specialists.

\section{DISCUSSION}

In a submontane landscape of the western Czech Republic, Brenthis ino occurs in high densities, its abundance and frequency of occurrence exceed those of other characteristic butterflies of humid meadows. It exhibits a wide trophic range, its host plants are ubiquitous in the landscape. Flight distances realistically crossed by dispersing individuals exceed the distances separating areas without host plants. The wide distribution is further facili- 


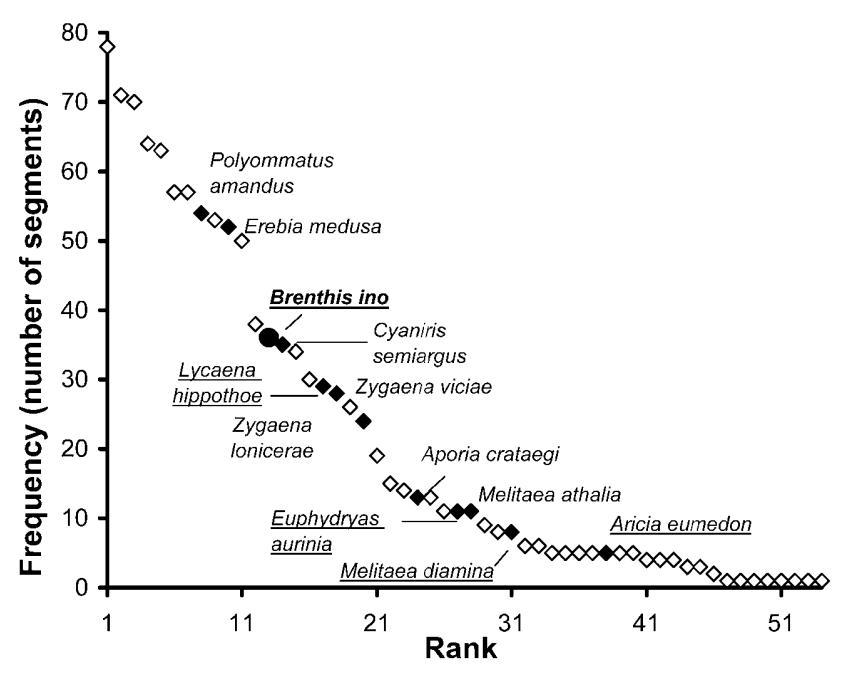

Fig. 6. Rank-frequency plot for butterflies observed during the transect census in piedmont of Doupovske Mts, western Bohemia, showing the frequency of Brenthis ino (filled circle) relative to associated species. Ten species that exhibited closest association with $B$. ino in a redundancy analysis are shown as filled diamonds; characteristic species of humid meadows are underlined.

tated by such life history traits as laying eggs singly and using patrolling tactic for mate location.

Our observations added two species, Potentilla erecta and Comarum palustre, to already known trophic range, further supporting the notion that $B$. ino feeds on a broad range of Rosaceae hosts. The locally used plants vary in biotope requirements (Kubát, 2002). Sanguisorba officinalis occurs in mown meadows with intermediate levels of nitrogen and humidity; Potentilla erecta prefers drier and nitrogen-poor mountain grasslands; and Comarum palustre is a characteristic species of peat bogs. We failed to observe oviposition on Filipendula ulmaria, which grows at abandoned nitrogen-rich sites. Some of the plants are locally abundant. This was not the case with rare and endangered Comarum, but both Sanguisorba and Potentilla were common in the study landscape and Filipendula locally dominated the vegetation. Further study of potential preference for individual hosts is urgently needed.

The effect of broad host plant range becomes apparent when $B$. ino is compared with co-occurring but declining species. At the study site, Melitaea diamina feeds solely on Valeriana dioica, a relatively rare plant (twelve transect segments). Similarly, Euphydryas aurinia feeds on Succisa pratensis (nine segments), and selects plants growing in low sward and relatively low humidity (Konvička et al., 2003).

The conjecture that broad trophic range and wide distribution of host plants translates into high local densities and wide landscape-scale distribution of a butterfly is far from trivial, because such clear-cut relationships are only rarely demonstrated. Our population used at least three (and possibly four) plants within one site. In contrast, many butterflies with seemingly broad host ranges differ in host use among populations (e.g., Kuussaari et al.,
2000; Wahlberg, 2001). Syntopic feeding on a wider range of plants is typical for generalists belonging to such groups as pierids, but seems to be rare among Argynnini fritillaries. It is noteworthy that another fritillary that has been recently expanding in the Czech Republic, Proclossiana eunomia, follows local increases of its host plant, Bistorta major, caused by abandonment of mountain meadows (Pavličko, 1996). Similarly, the only "large" fritillary still relatively common in the country, Argynnis aglaja, utilises a broader host range than its declining congenerics (Fric et al., 2005).

Dispersing individuals of $B$. ino easily locate habitable patches. There is an argument strongly suggesting that a dense distribution of resources is more important than innate mobility. In an inverse power function, the exponential parameter $n$ determines the length of frequencydistribution tail: the lower its value, the higher the distances that are crossed (Hovestadt et al., 2001). Considerably lower values than those detected for $B$. ino were reported, e.g., for the bog fritillary Boloria aquilonaris in Belgium, where it is threatened (Baguette, 2003), or for a widespread grassland satyrid Melanargia galathea (Vandewoestinje \& Baguette, 2004). Values ranging from 1 to 2 (close to 1.5 in B. ino) seem to be more frequent. However, they occur again both in declining and widespread species. They were found, among others, for Euphydryas maturna, the most severely threatened butterfly in the Czech Republic (Konvička et al., 2005). Within our MRR area, such values applied for the declining Euphydryas aurinia and Melitaea diamina, as well as for the still common M. athalia (unpubl. data). High propensity to move cannot generate a wide distribution under scarcity or absence of resources. Instead, species of intermediate mobility tend to suffer most severely if affected by habitat loss (Thomas, 2000).

The efficient dispersal of $B$. ino may be influenced by some subtler traits. Norberg et al. (2002) demonstrated that $B$. ino crossed shaded areas more readily than four other grassland species tested in a simultaneous outdoorcage experiment, perhaps owing to its larger size and hence more efficient thermoregulation (cf. Heinrich, 1986).

Another factor possibly contributing to the success of $B$. ino is its low selectivity for habitat architecture. Its males patrol, and hence can locate females over wide tracks of uniformly mown meadows. This contrasts with at least two other wet meadows butterflies, Lycaena helle and Euphydryas aurinia, which require meadows dissected by wind-shielded structures such as hedges, on which their males establish perches (Fisher et al., 1999; and unpublished observation). Furthermore, females of $B$. ino lay eggs singly, spreading the risks faced by progeny of individual females. Under such a strategy, it is unlikely that too exacting preferences for plants growing in particular conditions would have evolved. This is supported by our observation that they oviposited on both unmown and freshly mown plant individuals.

The number of eggs produced per female depends on female longevity. Argynnini relatives of $B$. ino are typical 
income breeders, whose females derive resources for egg production from adult diet (Boggs \& Ross, 1993; Boggs, 1997; O'Brien et al., 2004). In our study, the residence values for females were shorter than for males, but the estimates were biased due to the missing tail of female emergence. On the last marking day, average female wing wear was just $2.4(n=14)$, contrasting with 4.0 in males $(n=3)$, suggesting that many females would live for several more days. This and the maximum values for observed residency document that adults of $B$. ino are relatively long-lived, consistent with their incomebreeding strategy (Boggs, 1997; Kopper et al., 2001).

To summarise, the remarkably broad host plant range combined with a wide distribution of the host plants seems to be the primary factor facilitating the persistence of Brenthis ino in western Bohemia, and elsewhere in Europe (cf. Saarinen et al., 2003; Sawchik et al., 2003). Demographic and life history traits likely contribute to the success, but probably play a rather minor role. Availability of extensively used hay meadows with infrequently mown edges is crucial for further persistence of the species.

ACKNOWLEDGEMENTS. We thank to M. Bartoš, V. Čiháková, V. Hula, M. Klímová and M. Maradová for help in field. The study was supported by the Czech Academy of Sciences (B6007306/2003) and by the Czech Ministry of Education (6007665801).

\section{REFERENCES}

AgNes G. 2000: Schmetterlingszönosen des Feuchtgrünlandes in der Deutsch-Belgischen Hocheifel und Untersuchungen zur Eignung von Indikatorarten für die Differenzierung vernäßter Standorte. Diploma thesis, Institut für Evolutionsbiologie und Ökologie, Universität Bonn, Bonn, 83 pp. On-line: http://www.gregoragnes.de/Diplom/Diplomarbeit.pdf

anthes N., Fartmann T., Hermann G. \& Kaule G. 2003: Combining larval habitat quality and metapopulation structure the key for successful management of pre-alpine Euphydryas aurinia colonies. J. Insect Conserv. 7: 175-185.

Baguette M. 2003: Long distance dispersal and landscape occupancy in a metapopulation of the cranberry fritillary butterfly. Ecography 26: 153-160.

Baguette M. \& Schtickzelle N. 2003: Local population dynamics are important to the conservation of metapopulations in highly fragmented landscapes. J. Appl. Ecol. 40: 404-412.

Beneš J., KonvičKa M., Dvořák J., Fric Z., Havelda Z., PavLičKo A., VRABeC V. \& WeIDENhOFFER Z. 2002: [Butterflies of the Czech Republic: Distribution and Conservation] I., II. SOM, Prague, 857 pp. (in Czech, English summaries).

BogGS C.L. 1997: Reproductive allocation from reserves and income in butterfly species with differing adult diets. Ecology 78: 181-191.

Boggs C.L. \& Ross C.L. 1993: The effect of adult food limitation on life history traits in Speyeria mormonia (Lepidoptera, Nymphalidae). Ecology 74: 433-441.

EBert G. \& Rennwald E. 1991: Die Schmetterlinge BadenWürttembergs, Band 1: Tagfalter 1. Eugen Ulmer, Hohenheim, $552 \mathrm{pp}$.

Fisher K., Beinlich B. \& Plachter H. 1999: Population structure, mobility and habitat preferences of the violet copper Lycaena helle (Lepidoptera, Lycaenidae) in Western Ger- many - Implications for conservation. J. Insect Conserv. 3: $43-52$.

Fric Z., Klímová M., Hula V. \& KonvičKa M. 2005: Caterpillars of Argynnis aglaja (Linnaeus, 1758) (Lepidoptera, Nymphalidae) feeding on Bistorta major. Atalanta 36: 119-121.

HeInRICH B. 1986: Comparative thermoregulation of 4 montane butterflies of different mass. Physiol. Zool. 59: 616-626.

HeNRIKSEN H.J. \& KREUTZER I. 1982: The Butterflies of Scandinavia in Nature. Skandinavisk, Bogforlag A/S, Odense, 215 pp.

HiLl J.K., Thomas C.D. \& Lewis O.T. 1996: Effects of habitat patch size and isolation on dispersal by Hesperia comma butterflies: Implications for metapopulation structure. J. Anim. Ecol. 65: 725-735.

Hovestadt T., Messner S. \& Poethre H. J. 2001: Evolution of reduced dispersal mortality and "fat-tailed" dispersal kernels in autocorrelated landscapes. Proc. R. Soc. London (B) 268: 385-391.

HrubÝ K. 1964: Prodromus Lepidopterorum Slovaciae. SAV, Bratislava, 962 pp.

Hula V., KonvičKa M., PavličKo A. \& Fric Z. 2004: Marsh Fritillary (Euphydryas aurinia) in the Czech Republic: Monitoring, metapopulation structure, and conservation of the endangered butterfly. Entomol. Fenn. 15: 231-241.

KARShOlt O. \& RAZOWSKI J. 1996: The Lepidoptera of Europe, a Distributional Checklist. Apollo Books, Stenstrup, 380 pp.

KonvičKa M., Hula V. \& Fric Z. 2003: Habitat of prehibernating larvae of the endangered butterfly Euphydryas aurinia (Lepidoptera: Nymphalidae): What can be learned from vegetation composition and architecture? Eur. J. Entomol. 100: 313-322.

KonvičKa M., ČížEK O., Filipová L., Fric Z., Beneš J., KrupKa M., ZÁmeČNíK J. \& DoČKALOvÁ Z. 2005: For whom the bells toll: Demography of the last population of the butterfly Euphydryas maturna in the Czech Republic. Biologia (in press).

Kopper B.J., Margolies D.C. \& Charlton R.E. 2001: Life history notes on the regal fritillary, Speyeria idalia (Drury) (Lepidoptera: Nymphalidae), in Kansas tallgrass prairie. $J$. Kans. Entomol. Soc. 74: 172-177.

KREBS C.J. 1989: Ecological Methodology. Harper \& Collins, New York, $654 \mathrm{pp}$.

KubÁt K. (ed.) 2002: Klíč ke květeně České republiky [Key to Flora of the Czech Republic]. Academia, Praha, 927 pp. (in Czech).

Kuras T., Beneš J., Fric Z. \& KonvičKa M. 2003: Dispersal patterns of endemic alpine butterflies with contrasting population structures: Erebia epiphron and E. sudetica. Popul. Ecol. 45: 115-123.

KuUssaari M., Singer M. \& HANSKI I. 2000: Local specialization and landscape-level influence on host use in an herbivorous insect. Ecology 81: 2177-2187.

MaEs D. \& VAN DyCK H. 2001: Butterfly diversity loss in Flanders (north Belgium): Europe's worst case scenario? Biol. Conserv. 99: 263-276.

Neve G., Barascud B., Hughes R., Aubert J., Descimon H., Lebrun P. \& Baguette M. 1996: Dispersal, colonization power and metapopulation structure in the vulnerable butterfly Proclossiana eunomia (Lepidoptera: Nymphalidae). $J$. Appl. Ecol. 33: 14-22

Norberg U., ENFJÄll K. \& Leimar O. 2002: Habitat exploration in butterflies - an outdoor cage experiment. Evol. Ecol. 16: $1-14$.

O’Brien D.M., Boggs C.L. \& Fogel M.L. 2004: Making eggs from nectar: the role of life history and dietary carbon turn- 
over in butterfly reproductive resource allocation. Oikos 105: 279-291.

PAvLIČKo A. 1996: Rozšíření perlet'ovce mokřadního (Proclossiana eunomia) na Šumavě a jeho vztah k hospodaření v krajině [The distribution of Proclossiana eunomia in the Šumava Mts and impacts of landscape management]. Silva Gabreta 1: 197-202 (in Czech).

Pollock K.H., Nichols J.D., Brownie C. \& Hines J.E. 1990: Statistical inference for capture-recapture experiments. Wildlife Monogr. 107: 1-97.

SaArinen K., Lahti T. \& Martilla O. 2003: Population trends of Finnish butterflies (Lepidoptera: Hesperioidea, Papilionoidea) in 1991-2000. Biodivers. Conserv. 12: 2147-2159

SawchiK J., Dufrêne M. \& Lebrun P. 2003: Estimation of habitat quality based on plant community, and effects of isolation in a network of butterfly habitat patches. Acta Oecol. 24: $25-33$.

Schneider C., Dover J. \& Fry G.L.A. 2003: Movement of two grassland butterflies in the same habitat network: the role of adult resources and size of the study area. Ecol. Entomol. 28: 219-227.

SchWeizerischer Bund FÜr NAturschutz [= SBN] 1987: Tagfalter und ihre Lebensräume. Fotorotar, Egg, 516 pp.

Schtickzelle N. \& Baguette M. 2004: Metapopulation viability analysis of the bog fritillary butterfly using RAMAS/GIS. Oikos 104: 277-290.

Settele J., Feldmann R. \& Reinhardt R. 1999: Die Tagfalter Deutschlands. Eugen Ulmer, Stuttgart, 452 pp.

Sutcliffe O.L., Thomas C.D. \& Peggie D. 1997: Areadependent migration by ringlet butterflies generates a mixture of patchy population and metapopulation attributes. Oecologia 109: 229-234.

ŠvestKa M. 1992: Perlet'ovec kopřivový, Brenthis ino (Rottemburg 1775), nový druh motýlí fauny Jihozápadní Moravy [Lesser-Marbled Fritillary, a new butterfly for south-western Moravia]. Př́rodovědný Sborník Západomoravského Muzea v Třebići 18: 25-29 (in Czech).

TABASHNIK B.E. 1980: Population structure of pierid butterflies, 3. Pest population of Colias philodice eriphyle. Oecologia 47: $175-183$.

Ter Braak C.J.F. \& Šmilauer P. 2002: CANOCO Reference Manual and User's Guide to Canoco for Windows: Software for Canonical Community Ordination (version 4.52). Microcomputer Power (Ithaca, NY, USA), 500 pp.

THOMAS C.D. 2000: Dispersal and extinction in fragmented landscapes. Proc. R. Soc. London (B) 267: 139-145.

Tolman T. \& Lewington R. 1997: Butterflies of Britain and Europe. Harper and Collins, London, $320 \mathrm{pp}$.

Vandewoestijne S. \& Baguette M. 2004: Demographic versus genetic dispersal measures. Popul. Ecol. 46: 281-285.

Van Swaay C.A.M. \& Warren M.S. 1999: Red Data Book of European Butterflies (Rhopalocera). Nature and Environment Series No. 99. Council of Europe, Strasbourg, 260 pp.

WAHLBERG N. 2001: On the status of the scarce fritillary Euphydryas maturna (Lepidoptera : Nymphalidae) in Finland. Entomol. Fenn. 12: 244-250.

ZAR J.H. 1999: Biostatistical Analysis. 4th ed. Prentice-Hall, New York, 663 pp.

Received March 3, 2005; revised and accepted April 24, 2005 